\title{
PENINGKATAN KEPUASAN PASIEN FOKUS PADA KUALITAS PELAYANAN
}

\author{
Otong Karyono \\ Teknik Industri, Fakultas Teknik Universitas Majalengka \\ Email : otong_karyono@rocketmail.com
}

\begin{abstract}
ABSTRAK
Rumah sakit umum daerah (RSUD) Kabupaten Majalengka merupakan rumah sakit milik pemerintah daerah, yang memiliki tugas dan tanggung jawab memberikan pelayanan kesehatan bagi masyarakat Majalengka pada khususnya dan umumnya bagi masyarakat luar Majalengka. Oleh karena itu, pemerintah Kabupaten Majalengka dalam penyelenggaraan pelayanan harus mampu memberikan pelayanan yang sesuai dengan harapan pasien. Namun permasalahannya saat ini, Pemerintah di dalam menyelenggarakan pelayanan publik masih banyakdijumpai kekurangan sehingga jika dilihat dari segi kualitas masih jauh dari yangdiharapkan masyarakat. Penelitian ini menggunakan metode kuantitatif dengan teknik analisis yang digunakan adalah analisis regresi linier berganda. Sampel yang digunakan adalah pasien rawat jalan pengguna askeskin yang dirawat inap minimal 2 hari yang menggunakan jasa pelayanan kesehatan di RSUD Kabupaten Majalengka. Sumber data yang digunakan adalah data primer (kuesioner) dan data sekunder. Hasil penelitian menunjukkan bahwa factor-faktor pelayanan yang terdiri dari aspek tampilan fisik, kehandalan, daya tanggap, jaminan dan empati seluruhnya memiliki pengaruh yang positif dan signifikan terhadap kepuasan pasien rawat inap peserta Askeskin. Hasil penelitian menunjukkan bahwa pihak Rumah Sakit perlu kiranya untuk meningkatkan aspekaspek pelayanan dalam meningkatkan kualitas layanan Rumah Sakit kepada pasiennya.
\end{abstract}

\section{Kata Kunci : Kualitas Pelayanan dan Kepuasan Pasien}

\section{PENDAHULUAN}

Rumah sakit merupakan suatu organisasi yang bergerak di bidang pelayanan kesehatan yang sehari-hari melakukan kontak dengan pasien. Oleh karena itu sebuah rumah sakit harus mampu memenuhi kebutuhan yang diperlukan oleh pasien, sehingga dapat meningkatkan derajat kesehatan yang setinggi-tingginya. Kelanggengan suatu rumah sakit salah satunya ditentukan dari banyaknya jumlah pasien yang berkunjung ke rumah sakit untuk memperoleh jasa pelayanan kesehatan, semakin meningkatnya jumlah kunjungan pasien maka semakin baik keberadaan rumah sakit tersebut. Oleh karena itu, pemberian pelayanan yang berkualitas merupakan tuntutan pada sebuah rumah sakit terhadap pasiennya. Kualitas pelayanan sangat penting pada rumah sakit yang bergerak dalam bidang jasa. Menurut Tjiptono (2008:85) menyatakan secara sederhana kualitas pelayanan bias diartikan sebagai ukuran seberapa bagus tingkat pelayanan yang diberikan mampu sesuai dengan ekspektasi pelanggan. Dengan demikian perusahaan dapat memahami harapan serta kebutuhan pelanggan agar dapat memuaskan pelanggan.

Kualitas yang diberikan oleh rumah sakit, akan menimbulkan persepsi konsumen terhadap kualitas yang diberikan kepadanya. Sering kali terdapat perbedaan antara harapan konsumen dengan persepsi konsumen terhadap kualitas yang diberikan oleh perusahaan. Untuk mengetahui apakah rumah sakit telah memberikan kualitas jasa yang sesuai dengan harapan konsumen, maka perlu dilakukan evaluasi dari konsumennya. Kualitas pelayanan dalam suatu rumah sakit jasa meliputi lima dimensi meliputi keandalan (reliability), berwujud (tangible), daya tanggap (responsiveness), jaminan (assurance), dan empati (emphaty). Rumah sakit umum daerah (RSUD) Kabupaten Majalengka merupakan rumah sakit milik pemerintah daerah, yang memiliki tugas dan tanggung jawab memberikan pelayanan kesehatan bagi masyarakat Majalengka pada khususnya dan umumnya bagi masyarakat luar Majalengka. Oleh karena itu, pemerintah Kabupaten Majalengka dalam penyelenggaraan pelayanan harus mampu memberikan pelayanan yang sesuai dengan harapan pasien. Namun permasalahannya saat ini, Pemerintah di dalam menyelenggarakan pelayanan publik masih banyakdijumpai kekurangan sehingga jika dilihat dari segi kualitas masih jauh dari yangdiharapkan masyarakat.

Hal ini ditunjukkan dengan masih munculnya berbagai keluhan masyarakat melalui media massa. Jika kondisi ini tidak direspon oleh 
pemerintah maka akan dapat menimbulkan citra yang kurang baik terhadap pemerintah sendiri. Mengingat fungsi utama pemerintah adalah melayani masyarakat maka pemerintah perlu terus berupaya meningkatkan kualitas pelayanan publik (Men PAN, 2004 :5). Sesuai dengan amanat undang-undang bahwa kesehatan adalah hak setiap warga negara dan masyarakat miskin menjadi tanggungan pemerintah. Pemerintah mengadakan Asuransi Kesehatan Masyarakat Miskin (ASKESKIN). Penduduk yang memiliki kekurangan dalam hal perekonomian berhak untuk membuat atau menggunakan Askeskin untuk kesehatan. Permasalahan yang dijumpai pada permasalahan Askeskin adalah mengenai pelayanan yang diberikan kepada pasien pengguna Askeskin dinilai belum optimal, hal ini didasarkan pada pemeriksaan penunjang yang belum dapat dilayani oleh RSUD Kabupaten Majalengka, sehingga dilaksanakan dengan pihak luar RSUD Kabupaten Majalengka. Kurang tersedianya obat-obatan yang sangat dibutuhkan oleh peserta Askeskin, sehingga mereka masih harus membeli diluar RSUD Kabupaten Majalengka (Sumber : Hasil observasi, 2016).

Faktor-faktor di atas diharuskan pemerintah melakukan upaya-upaya perbaikan kualitas pelayanan Askeskin, sehingga pelayanan tersebut dapat dirasakan manfaatnya semaksimal mungkin dan meningkatkan derajat kesehatan. Banyak faktor yang mempengaruhi kepuasan pelanggan salah satunya adalah faktor pelayanan.Kualitas pelayanan guna mencapai kepuasan pasien. Meskipun demikian elemen ini mempengaruhi pasien dari segi biaya yang dikeluarkan, biasanya semakin mahal harga perawatan maka pasien mempunyai harapan yang lebih besar. Berdasarkan dari pemikiran ini dan uraian latar belakang di atas maka permasalahan yang diambil adalah: Pengaruh kualitas pelayanan askeskin yang terdiri dari variabel Reliability, Responsiveness, Assurance, Empathy dan Tangible terhadap kepuasan pasien pengunna Askeskin.

\section{METODE PENELITIAN}

Penelitian ini penulis menggunakan metode penelitian deskriptif verifikatif. Menurut Arikunto (2006:8) : Penelitian deskriptif yaitu penelitian yang bertujuan untuk memperoleh deskripsi tentang ciri-ciri variabel, sedangkan sifat penelitian verifikatif pada dasarnya ingin menguji kebenaran dari suatu hipotesis yang dilaksanakan melalui pengumpulan data di lapangan. Penelitian ini sebagai penelitian deskriptif verifikatif dengan pendekatan kuantitatif dan kuantitatif. Penelitian deskriptif verifikatif, karena menyajikan gambaran terstruktur, factual, dan akurat mengenai fakta-fakta yang berkaitan dengan kualitas pelayanan dan kepuasan pasien pengguna Askeskin RSUD Kabupaten Majalengka.

Populasi yang akan diteliti harus didenifisikan dengan jelas sebelum penelitiandilakukan (Tripriyono, 2005:76). Populasi dapat pula tidak terbatas. Populasi memilikikarakteristik yang dapat diperkirakan dan diklasifikasikan sesuai dengan keperluanpenelitian. Atribut merupakan karakteristik khusus yang dapat dimiliki atau tidak dimilikioleh setiap sampel. Populasi dalam penelitian ini adalah pasien pengguna askeskin yang dirawat inap minimal 2 hari yang menggunakan jasa pelayanan kesehatan di RSUD Kabupaten Majalengka, sebanyak 180 pasien. Sampel adalah bagian dari jumlah dan karakteristik yang dimiliki oleh populasi tersebut. Penentuan jumlah sampel ditentukan dengan menggunakan beberapa metode antaralain dengan menggunakan rumus Slovin. Dari hasil penghitungan sampel diatas, maka jumlah sampel dalam penelitian ini dibulatkan sebanyak 125 responden.

\section{HASIL DAN PEMBAHASAN}

\section{Pengujian validitas dan Reliabilitas Instrumen}

Pada pengujian validitas data, seluruh indikator pada variabel pembentuk faktor-faktor pelayanan dan kepuasan pasien memiliki nilai $r$ hitung > r-tabel $(0,177)$, sehingga dikategorikan bahwa seluruh indikator pada variabel faktorfaktor pelayanan memiliki validitas yang cukup baik. Sementara pada pengujian reliabilitas data, seluruh dimensi pembentuk variabel faktor-faktor pelayanan dan kepuasan pasien memiliki nilai alpha > r-kritis; sehingga diasumsikan bahwa seluruh variabel penelitian memiliki kehandalan yang cukup baik.

\section{Uji Asumsi Analisis Regresi}

Pemenuhan terhadap analisis regresi linier berganda harus melewati pengujian kualitas data, di antaranya uji multikolinearitas, heteroskedasitas dan normalitas sebagaimana diuraikan sebagai berikut :

\section{a. Uji Multikolinearitas}

Uji multikolinearitas digunakan untuk mengetahui ada atau tidaknya penyimpangan asumsi klasik multikolinearitas yaitu adanya 
hubungan linear antar variabel independen dalam model regresi. Prasyarat yang harus terpenuhi dalam model regresi adalah tidak adanya multikolinearitas. Ada beberapa metode pengujian yang bisa digunakan diantaranya yaitu 1) dengan melihat nilai inflation factor (VIF) pada model regresi, 2) dengan membandingkan nilai koefisien determinasi individual $(\mathrm{r} 2)$ dengan nilai determinasi secara serentak $\left(\mathrm{R}^{2}\right)$, dan 3$)$ dengan melihat nilai eigen value dan condition index. Pada pembahasan ini akan dilakukan uji multikolinearitas dengan melihat nilai inflation factor (VIF) pada model regresi dan membandingkan nilai koefisien determinasi individual ( $\mathrm{r}$ 2) dengan nilai determinasi secara serentak (R2). Menurut Santoso (2001), pada umumnya jika VIF lebih besar dari 5, maka variabel tersebut mempunyai persoalan multikolinearitas dengan variabel bebas lainnya.

Tabel 1 Hasil uji Multikolinearitas

\begin{tabular}{|c|c|c|}
\hline \multirow[t]{2}{*}{ Model } & \multicolumn{2}{|c|}{ Collinearity Statistics } \\
\hline & Tolerance & VIF \\
\hline (Constant) & & \\
\hline Bukti_Fisik & .270 & 3.705 \\
\hline Kehandalan & .295 & 3.392 \\
\hline $\begin{array}{l}\text { Daya_Tang } \\
\text { gap }\end{array}$ & .296 & 3.376 \\
\hline Jaminan & .262 & 3.814 \\
\hline Empati & .438 & 2.286 \\
\hline
\end{tabular}

Dari hasil di atas dapat diketahui nilai variance inflation factor(VIF) untuk variabel bukti fisik sebesar 3,705; kehandalan sebesar 3,392, daya tanggap sebesar 3,376, jaminan sebesar 3,814 dan empati sebesar 2,286 lebih kecil dari 5, sehingga bisa diduga bahwa antar variabel independen tidak terjadi persoalan multikolinearitas.

\section{b. Pengujian Heteroskedasitas}

Uji heteroskedastisitas digunakan untuk mengetahui ada atau tidaknya penyimpangan asumsi klasik heteroskedastisitas yaitu adanya ketidaksamaan varian dari residual untuk semua pengamatan pada model regresi. Prasyarat yang harus terpenuhi dalam model regresi adalah tidak adanya gejala heteroskedastisitas.

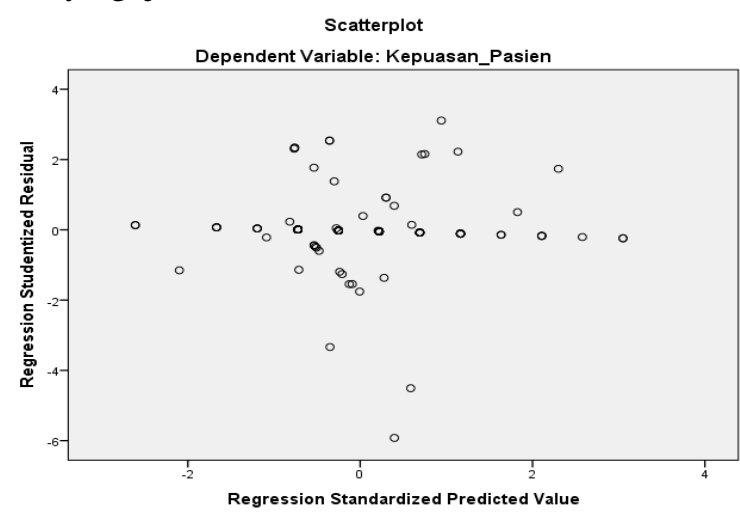

Gambar 1 Hasil pengujian Heteroskedasitas Sumber : data penelitian diolah, 2016

Dilihat dari gambartidak ada pola yang jelas, serta titik-titik menyebar diatas dan dibawah angka 0 pada sumbu $\mathrm{Y}$, maka tidak terjadi heteroskedastisitas.

\section{c. Pengujian Normalitas Data}

Uji normalitas data dimaksudkan untuk memperlihatkan bahwa data sampel berasal dari populasi yang berdistribusi normal. Ada beberapa teknik yang dapat digunakan untuk menguji normalitas data dengan Teknik KolmogorovSmirnov, dengan SPSS versi 20.0. Uji Kolmogorov-Smirnov termasuk dalam uji nonparametrik untuk kasus satu sampel. Uji ini digunakan untuk menguji asumsi normalitas data. Tes dalam uji ini adalah tes goodness of fit yang mana tes tersebut untuk mengukur tingkat kesesuian antara distribusi serangkaian sampel (data observasi) dengan distribusi teoritis tertentu.

Tabel 2 Hasil pengujian Normalitas Data

\begin{tabular}{|c|c|c|c|c|c|c|c|}
\hline & $\begin{array}{l}\text { Bukti_ } \\
\text { fisik }\end{array}$ & $\begin{array}{c}\text { Kehandal- } \\
\text { an }\end{array}$ & $\begin{array}{c}\text { Daya_ } \\
\text { Tanggap }\end{array}$ & Jaminan & Empati & $\begin{array}{c}\text { Kepuasan_P } \\
\text { asien }\end{array}$ \\
\hline \multicolumn{2}{|l|}{$\mathrm{N}$} & 125 & 125 & 125 & 125 & 125 & 125 \\
\hline \multirow[b]{2}{*}{$\begin{array}{l}\text { Normal } \\
\text { Parameters }\end{array}$} & Mean & 10.55946 & 10.74282 & 12.86540 & 16.68377 & 13.12371 & 12.86172 \\
\hline & $\begin{array}{l}\text { Std. } \\
\text { Deviation }\end{array}$ & 1.869578 & 1.802196 & 3.329798 & 3.126439 & 2.675541 & 3.336324 \\
\hline \multirow{3}{*}{$\begin{array}{l}\text { Most } \\
\text { Extreme } \\
\text { Differences }\end{array}$} & Absolute & .119 & 108 & .076 & .096 & .104 & .071 \\
\hline & Positive & .119 & .078 & .054 & .090 & .104 & .056 \\
\hline & Negative & -.097 & -.108 & -.076 & -.096 & -.100 & -.071 \\
\hline \multicolumn{2}{|c|}{ Kolmogorov-Smirnov Z } & 1.327 & 1.209 & .851 & 1.077 & 1.164 & .792 \\
\hline \multicolumn{2}{|c|}{ Asymp. Sig. (2-tailed) } & .059 & .107 & .465 & 197 & .133 & .557 \\
\hline
\end{tabular}


Sumber : data penelitian diolah, 2016

Dari Hasil tabel di atas menunjukkan uji normalitas data faktor-faktor pelayanan dengan kepuasan pasien, dengan menggunakan teknik analisis Kolmogorov-Smirnov. Pengujian dengan SPSS berdasarkan pada uji KolmogorovSmirnov. Hipotesis yang diuji adalah:

Ho : Sampel berasal dari populasi yang berdistribusi normal

Ha : Sampel tidak berasal dari populasi yang berdistribusi normal

Dengan demikian, normalitas dipenuhi jika hasil uji tidak signifikan untuk suatu taraf signifikansi $(\alpha)$ tertentu (biasanya $\alpha=0,05$ atau $\alpha=0,01)$. Sebaliknya, jika hasil uji signifikan maka normalitas data tidak terpenuhi. Cara mengetahui signifikan atau tidak signifikan hasil uji normalitas adalah dengan memperhatikan bilangan pada kolom signifikansi (Sig.) untuk menetapkan kenormalan, kriteria yang berlaku adalah sebagai berikut:

1. Tetapkan taraf signifikansi uji misalnya $\alpha=0,05$

2. Bandingkan $\mathrm{p}$ dengan taraf signifikansi yang diperoleh

3. Jika signifikansi yang diperoleh $>\alpha$, maka sampel berasal dari populasi yang berdistribusi normal.

4. Jika signifikansi yang diperoleh $<\alpha$, maka sampel bukan berasal dari populasi yang berdistribusi normal.
Pada hasil di atas diperoleh nilai signifikansi bukti fisik sebesar $p=0,059$, kehandalan sebesar $\mathrm{p}=0,107$, daya tanggap sebesar $p=0,465$, jaminan sebesar $p=0,197$, dan empati sebesar $p=0,133$ dan kepuasan pasien sebesar $\mathrm{p}=0,557$ sehingga $\mathrm{p}>\alpha$. Dengan demikian sampel berasal dari populasi yang berdistribusi normal.

\section{d. Analisis Regresi Linier Berganda dan Uji Hipotesis}

\section{Perhitungan Kontribusi Pengaruh}

Analisis regresi linier berganda pada penelitian ini bertujuan untuk mengetahui hubungan secara linear antara dua atau lebih variabel independen faktor-faktor pelayanan yang terdiri dari bukti fisik, kehandalan, daya tanggap, jaminan dan empati dengan variabel dependen (kepuasan pasien). Analisis ini untuk mengetahui arah hubungan antara variabel independen dengan variabel dependen apakah masing-masing variabel independen berhubungan positif atau negatif dan untuk memprediksi nilai dari variabel dependen apabila nilai variabel independen mengalami kenaikan atau penurunan. Adapun hasil analisis regresi linier berganda diuraikan sebagai berikut :

Tabel 3 Hasil Analisis Regresi Linier Berganda

\begin{tabular}{|c|c|c|c|c|c|c|}
\hline & \multirow[t]{2}{*}{ Model } & \multicolumn{2}{|c|}{$\begin{array}{l}\text { Unstandardized } \\
\text { Coefficients }\end{array}$} & \multirow{2}{*}{$\begin{array}{c}\begin{array}{c}\text { Standardize } \\
\text { d } \\
\text { Coefficients }\end{array} \\
\text { Beta }\end{array}$} & \multirow[t]{2}{*}{$\mathrm{t}$} & \multirow[t]{2}{*}{ Sig. } \\
\hline & & B & $\begin{array}{l}\text { Std. } \\
\text { Error }\end{array}$ & & & \\
\hline & (Constant) & .340 & .551 & & .616 & .539 \\
\hline & Bukti_Fisik & .147 & .066 & .152 & 2.241 & 027 \\
\hline & Kehandalan & .469 & .065 & 467 & 7.182 & .000 \\
\hline 1 & Daya_Tanggap & .031 & .065 & .031 & .479 & .633 \\
\hline & Jaminan & .175 & .068 & 178 & 2.579 & .011 \\
\hline & Empati & .204 & .055 & 197 & 3.700 & .000 \\
\hline
\end{tabular}

Sumber : data penelitian diolah, 2016

Keterangan:

Berdasarkan Tabel di atas, dapat diketahui $\mathrm{Y}^{\prime} \quad$ = Kepuasan Pasien

persamaan analisis regresi linier berganda a $=$ konstanta sebagai berikut :

$$
\begin{array}{lll}
Y^{\prime}=a+b_{1} X_{1}+b_{2} X_{2}+\ldots . .+b_{n} X_{n} ; & X_{1}=\text { bukti fisik } \\
Y^{\prime}=0,340+0,147 X_{1}+0,469 X_{2}+0,469 X_{3} & X_{2}=\text { kehandalan }
\end{array}
$$$$
\mathrm{b}_{1}, \mathrm{~b}_{2}=\text { koefisien regresi }
$$$$
\mathrm{X}_{1} \quad \text { = bukti fisik }
$$$$
+0,175 \mathrm{X}_{4}+0,204 \mathrm{X}_{5}
$$$$
\mathrm{X}_{3} \quad \text { = daya tanggap }
$$ 
$\mathrm{X}_{4}=$ jaminan

$\mathrm{X}_{5} \quad=$ empati

Persamaan regresi di atas dapat dijelaskan sebagai berikut:

a) Konstanta sebesar 0,340; artinya jika bukti fisik $\left(\mathrm{X}_{1}\right)$, kehandalan $\left(\mathrm{X}_{2}\right)$, daya tanggap $\left(X_{3}\right)$, jaminan $\left(X_{4}\right)$ dan empati $\left(X_{5}\right)$ nilainya adalah 0 , maka harga kepuasan pasien ( $\left.\mathrm{Y}^{\prime}\right)$ nilainya adalah sebesar 0,340 . .

b) Koefisien regresi variabel bukti fisik $\left(X_{1}\right)$ sebesar 0,147; artinya jika variabel independen lain nilainya tetap dan bukti fisik mengalami kenaikan $1 \%$, maka nilai kepuasan pasien (Y') akan mengalami kenaikan sebesar 0,147 .

c) Koefisien regresi variabel kehandalan $\left(\mathrm{X}_{2}\right)$ sebesar 0,467; artinya jika variabel independen lain nilainya tetap dan kehandalan mengalami kenaikan $1 \%$, maka nilai kepuasan pasien (Y') akan mengalami kenaikan sebesar 0,467 .

d) Koefisien regresi variabel daya tanggap $\left(\mathrm{X}_{3}\right)$ sebesar 0,031; artinya jika variabel independen lain nilainya tetap dan daya tanggap mengalami kenaikan $1 \%$, maka nilai kepuasan pasien (Y') akan mengalami kenaikan sebesar 0,031.

e) Koefisien regresi variabel jaminan $\left(\mathrm{X}_{4}\right)$ sebesar 0,178; artinya jika variabel independen lain nilainya tetap dan jaminan mengalami kenaikan $1 \%$, maka nilai kepuasan pasien (Y') akan mengalami kenaikan sebesar 0,178 .

f) Koefisien regresi variabel empati $\left(X_{5}\right)$ sebesar 0,197; artinya jika variabel independen lain nilainya tetap dan empati mengalami kenaikan $1 \%$, maka nilai kepuasan pasien ( $\left.Y^{\prime}\right)$ akan mengalami kenaikan sebesar 0,197.

Selanjutnya dilakukan perhitungan mengenai kontribusi pengaruh secara langsung yang diberikan oleh variabel independen terhadap variabel dependen, yang diuraikan sebagai berikut :

a) Pengaruh langsung dari dimensi bukti fisik $\left(\mathrm{X}_{1}\right)$ terhadap kepuasan pasien $(\mathrm{Y})$ memiliki nilai koefisien regresi / Standardized Coefficients sebesar 0,152; sehingga kontribusi langsung yang diberikan oleh dimensi bukti fisik sebesar $(0,152)^{2} \times 100 \%=$ $2,31 \%$. Artinya dimensi bukti fisik memiliki pengaruh secara langsung terhadap kepuasan pasien sebesar $2,31 \%$.

b) Pengaruh langsung dari dimensi kehandalan $\left(\mathrm{X}_{2}\right)$ terhadap kepuasan pasien $(\mathrm{Y})$ memiliki nilai koefisien regresi / Standardized Coefficients sebesar 0,467; sehingga kontribusi langsung yang diberikan oleh dimensi kehandalan sebesar $(0,467)^{2}$ x $100 \%$ $=21,81 \%$. Artinya dimensi kehandalan memiliki pengaruh secara langsung terhadap kepuasan pasien sebesar $21,81 \%$.

c) Pengaruh langsung dari dimensi daya tanggap $\left(\mathrm{X}_{3}\right)$ terhadap kepuasan pasien $(\mathrm{Y})$ memiliki nilai koefisien regresi / Standardized Coefficients sebesar 0,031; sehingga kontribusi langsung yang diberikan oleh dimensi daya tanggap sebesar $(0,031)^{2} \mathrm{x}$ $100 \%=0,0961 \%$. Artinya dimensi daya tanggap memiliki pengaruh secara langsung terhadap kepuasan pasien sebesar 0,0961\%.

d) Pengaruh langsung dari dimensi jaminan $\left(\mathrm{X}_{4}\right)$ terhadap kepuasan pasien $(\mathrm{Y})$ memiliki nilai koefisien regresi / Standardized Coefficients sebesar 0,178; sehingga kontribusi langsung yang diberikan oleh dimensi jaminan sebesar $(0,178)^{2} \times 100 \%=3,168 \%$. Artinya dimensi jaminan memiliki pengaruh secara langsung terhadap kepuasan pasien sebesar 3,168\%.

e) Pengaruh langsung dari dimensi empati $\left(X_{5}\right)$ terhadap kepuasan pasien (Y) memiliki nilai koefisien regresi / Standardized Coefficients sebesar 0,197; sehingga kontribusi langsung yang diberikan oleh dimensi empati sebesar $(0,197)^{2} \times 100 \%=3,88 \%$. Artinya dimensi empati memiliki pengaruh secara langsung terhadap kepuasan pasien sebesar 3,88\%.

\section{Koefisien Determinasi}

Untuk mengetahui besarnya pengaruh antara kedua variabel kepemimpinan kepala madrasah dan iklim organisasi terhadap kepuasan kerja adalah melalui perhitungan koefisien determinasi. Koefisien Determinasi (R) didapat dari hasil pengkuadratan koefisien korelasi ( $r$ ) atau $R=r^{2}$.

Sejalan dengan itu, maka menurut Nugroho (1990 : 452) "koefisien determinasi (coefficient of determination) diberi lambang $\mathrm{r}^{2}$, yaitu koefisien yang menunjukan (to determine $=$ menceritakan berapa besar peranan faktor $X_{1}$ dan $\mathrm{X}_{2}$ dalam menentukan besar $\mathrm{Y}$ )". Pengaruh secara simultan dapat dilihat dari nilai koefisien determinasi sebagai berikut :

Tabel 4 Koefisien Determinasi

Model Summary

\begin{tabular}{|c|c|c|c|c|}
\hline Model & $\mathrm{R}$ & R Square & $\begin{array}{c}\text { Adjusted R } \\
\text { Square }\end{array}$ & $\begin{array}{l}\text { Std. Error of } \\
\text { the Estimate }\end{array}$ \\
\hline 1 & $.923^{\mathrm{a}}$ & .852 & .846 & .927347 \\
\hline
\end{tabular}


Sumber : data penelitian diolah, 2016

Dari responden pasien pasca perawatan, dengan nilai $(\mathrm{R}=0,923)$ maka koefisien determinasi $\left(\mathrm{R}=\mathrm{R}^{2}=0,923=0,852\right)$ atau 85,20 $\%$. Hal ini menunjukan pengaruh variabel $\mathrm{X}_{1}, \mathrm{X}_{2}$, $\mathrm{X}_{3}, \mathrm{X}_{4}$ dan $\mathrm{X}_{5}$ terhadap $\mathrm{Y}$ sebesar $85,20 \%$, sisanya $26,40 \%$ dipengaruhi oleh variabel lain yang tidak diteliti. Secara kuantitatif determinasi $14,80 \%$ tersebut menunjukkan kontribusi faktor-faktor pelayanan yang terdiri dari bukti fisik, kehandalan, daya tanggap, jaminan dan empati terhadap kepuasan pasien relatif besar dan mempunyai hubungan yang cukup kuat.

\section{Pengujian Hipotesis}

Pada penelitian ini uji hipotesis terdiri dari 2 bagian, yaitu hipotesis secara parsial dan simultan. Adapun penjelasan mengenai pengujian hipotesis diuraikan sebagai berikut :

\section{Pengujian I : Pengaruh bukti fisik terhadap kepuasan pasien}

Hasil uji statistik pengaruh bukti fisik terhadap kepuasan pasien dengan menggunakan hipotesis :

$$
\begin{array}{cl}
\mathrm{H}_{0}: \beta_{\mathrm{x} 1 \mathrm{y}}=0 \quad: \quad \begin{array}{l}
\text { Bukti fisik tidak } \\
\text { berpengaruh terhadap } \\
\text { kepuasan pasien }
\end{array} \\
\mathrm{H}_{1}: \beta_{\mathrm{x} 1 \mathrm{y}} \neq 0: \begin{array}{l}
\text { Bukti fisik } \\
\text { berpengaruh terhadap } \\
\text { kepuasan pasien }
\end{array}
\end{array}
$$

Dengan kriteria uji : tolak $\mathrm{H}_{0}$ jika Sig. $<0.05$ atau $\mathrm{t}$ hitung $>\mathrm{t}$ tabel.

Tabel 5 Pengaruh Bukti fisik $\left(\mathrm{X}_{1}\right)$ terhadap kepuasan pasien $(\mathrm{Y})$

\begin{tabular}{|c|c|c|c|l|}
\hline Struktural & $\begin{array}{c}\text { Koefisien } \\
\text { regresi }\end{array}$ & $\begin{array}{c}\mathbf{t} \\
\text { hitung }\end{array}$ & Sign. & Kesimpulan \\
\hline$\beta_{\mathrm{xly}}$ & 0,152 & 2,241 & 0.027 & $\begin{array}{l}\text { Ho ditolak, } \\
\text { terdapat } \\
\text { pengaruh } \mathrm{X}_{1} \\
\text { terhadap Y }\end{array}$ \\
\hline
\end{tabular}

Sumber : data penelitian diolah, 2016

Hasil perhitungan di atas menunjukkan nilai $\mathrm{t}$ hitung adalah 2,241 dengan tingkat signifikansi $(\alpha)=5 \%$. diperoleh nilai Sign. $=0.000$. Sesuai dengan hasil yang diperoleh yaitu Sign.( 0.027) < 0.05 serta t-hitung $(2,241)>$ t-tabel $(1.979)$. Nilai $\mathrm{t}$-tabel didapatkan dengan rumus $\mathrm{dk}=\mathrm{n}-\mathrm{k}$; sehingga nilai $\mathrm{dk}=125-5$ didapat nilai $\mathrm{t}$-tabel sebesar 1,979. Hasil di atas dideskripsikan bahwa $\mathbf{H}_{\mathbf{0}}$ ditolak dan $\mathbf{H}_{\mathbf{1}}$ diterima, dengan demikian dapat disimpulkan bahwa bukti fisik memiliki pengaruh terhadap kepuasan pasien.

\section{Pengujian II : Pengaruh kehandalan terhadap kepuasan pasien}

Hasil uji statistik pengaruh bukti fisik terhadap kepuasan pasien dengan menggunakan hipotesis :

$$
\begin{aligned}
& \mathrm{H}_{0}: \beta_{\mathrm{x} 2 \mathrm{y}}=0 \quad: \quad \text { Kehandalan tidak } \\
& \text { berpengaruh } \\
& \text { terhadap kepuasan } \\
& \text { pasien } \\
& \mathrm{H}_{1}: \beta_{\mathrm{x} 2 \mathrm{y}} \neq 0 \quad: \quad \text { Kehandalan } \\
& \text { berpengaruh } \\
& \text { terhadap kepuasan } \\
& \text { pasien }
\end{aligned}
$$

Dengan kriteria uji : tolak $\mathrm{H}_{0}$ jika Sig. $<0.05$ atau $\mathrm{t}$ hitung $>\mathrm{t}$ tabel.

Tabel 6 Pengaruh Kehandalan $\left(\mathrm{X}_{2}\right)$ terhadap kepuasan pasien $(\mathrm{Y})$

\begin{tabular}{|c|r|r|r|l|}
\hline truktural & $\begin{array}{c}\text { Koefisien } \\
\text { regresi }\end{array}$ & t hitung & Sign. & Kesimpulan \\
\hline$\beta_{\mathrm{x} 2 \mathrm{y}}$ & 0,467 & 7,182 & 0.000 & $\begin{array}{l}\text { Ho ditolak, } \\
\text { terdapat } \\
\text { pengaruh } \mathrm{X}_{2} \\
\text { terhadap Y }\end{array}$ \\
\hline
\end{tabular}

Sumber : data penelitian diolah, 2016

Hasil perhitungan di atas menunjukkan nilai $t$ hitung adalah 2,241 dengan tingkat signifikansi $(\alpha)=5 \%$. diperoleh nilai Sign. $=0.000$. Sesuai dengan hasil yang diperoleh yaitu Sign. ( 0.000) < 0.05 serta t-hitung $(7,182)>$ t-tabel $(1.979)$. Nilai $\mathrm{t}$-tabel didapatkan dengan rumus $\mathrm{dk}=\mathrm{n}-\mathrm{k}$; sehingga nilai $\mathrm{dk}=125-5$ didapat nilai $\mathrm{t}$-tabel sebesar 7,182. Hasil di atas dideskripsikan bahwa $\mathbf{H}_{0}$ ditolak dan $\mathbf{H}_{1}$ diterima, dengan demikian dapat disimpulkan bahwa kehandalan memiliki pengaruh terhadap kepuasan pasien.

\section{Pengujian III : Pengaruh daya tanggap terhadap kepuasan pasien}

Hasil uji statistik pengaruh daya tanggap terhadap kepuasan pasien dengan menggunakan hipotesis :

$$
\begin{aligned}
\mathrm{H}_{0}: \beta_{\text {x3y }}=0 \quad: \quad \begin{array}{l}
\text { Daya tanggap tidak } \\
\text { berpengaruh terhadap } \\
\text { kepuasan pasien }
\end{array} \\
\mathrm{H}_{1}: \beta_{\text {x3y }} \neq 0: \begin{array}{l}
\text { Daya tanggap } \\
\text { berpengaruh terhadap } \\
\text { kepuasan pasien }
\end{array}
\end{aligned}
$$

Dengan kriteria uji : tolak $\mathrm{H}_{0}$ jika Sig. $<0.05$ atau $\mathrm{t}$ hitung $>\mathrm{t}$ tabel. 
Tabel 7 Pengaruh daya tanggap $\left(\mathrm{X}_{3}\right)$ terhadap kepuasan pasien $(\mathrm{Y})$

\begin{tabular}{|c|r|r|r|l|}
\hline Struktural & $\begin{array}{c}\text { Koefisien } \\
\text { regresi }\end{array}$ & $\begin{array}{c}\mathbf{t} \\
\text { hitung }\end{array}$ & Sign. & Kesimpulan \\
\hline$\beta_{\mathrm{x} 3 \mathrm{y}}$ & 0,031 & 0,479 & 0.633 & $\begin{array}{l}\text { Ho } \\
\text { diterima, } \\
\text { tidak } \\
\text { terdapat } \\
\text { pengaruh } \mathrm{X}_{3} \\
\text { terhadap Y }\end{array}$ \\
\hline
\end{tabular}

Sumber : data penelitian diolah, 2016

Hasil perhitungan di atas menunjukkan nilai $t$ hitung adalah 2,241 dengan tingkat signifikansi $(\alpha)=5 \%$. diperoleh nilai Sign. $=0.000$. Sesuai dengan hasil yang diperoleh yaitu Sign.( 0.633) > 0.05 serta t-hitung $(0,479)<$ t-tabel $(1.979)$. Nilai $\mathrm{t}$-tabel didapatkan dengan rumus $\mathrm{dk}=\mathrm{n}-\mathrm{k}$; sehingga nilai $\mathrm{dk}=125-5$ didapat nilai $\mathrm{t}$-tabel sebesar 0,479. Hasil di atas dideskripsikan bahwa $\mathbf{H}_{\mathbf{0}}$ diterima dan $\mathbf{H}_{\mathbf{1}}$ ditolak, dengan demikian dapat disimpulkan bahwa daya tanggap tidak memiliki pengaruh terhadap kepuasan pasien.

\section{Pengujian IV : Pengaruh jaminan terhadap kepuasan pasien}

Hasil uji statistik pengaruh jaminan terhadap kepuasan pasien dengan menggunakan hipotesis :

$$
\begin{array}{ll}
\mathrm{H}_{0}: \beta_{\mathrm{x} 4 \mathrm{y}}=0 \quad: & \begin{array}{l}
\text { Jaminan tidak } \\
\text { berpengaruh terhadap } \\
\text { kepuasan pasien }
\end{array} \\
\mathrm{H}_{1}: \beta_{\mathrm{x} 4 \mathrm{y}} \neq 0: \begin{array}{l}
\text { Jaminan berpengaruh } \\
\text { terhadap kepuasan } \\
\text { pasien }
\end{array}
\end{array}
$$

Dengan kriteria uji : tolak $\mathrm{H}_{0}$ jika Sig. $<0.05$ atau $\mathrm{t}$ hitung $>\mathrm{t}$ tabel.

Tabel 8 Pengaruh Jaminan $\left(\mathrm{X}_{4}\right)$ terhadap kepuasan pasien (Y)

\begin{tabular}{|c|r|r|c|l|}
\hline Struktural & $\begin{array}{c}\text { Koefisien } \\
\text { regresi }\end{array}$ & $\begin{array}{c}\mathbf{t} \\
\text { hitung }\end{array}$ & Sign. & Kesimpulan \\
\hline$\beta_{\mathrm{x} 4 \mathrm{y}}$ & 0,178 & 2,579 & 0.011 & $\begin{array}{l}\text { Ho ditolak, } \\
\text { terdapat } \\
\text { pengaruh } \mathrm{X}_{4} \\
\text { terhadap Y }\end{array}$ \\
\hline
\end{tabular}

Sumber : data penelitian diolah, 2016

Hasil perhitungan di atas menunjukkan nilai $\mathrm{t}$ hitung adalah 2,241 dengan tingkat signifikansi $(\alpha)=5 \%$. diperoleh nilai Sign. $=0.000$. Sesuai dengan hasil yang diperoleh yaitu Sign. $(0.011)<$ 0.05 serta t-hitung $(2,579)>$ t-tabel $(1.979)$. Nilai $\mathrm{t}$-tabel didapatkan dengan rumus $\mathrm{dk}=\mathrm{n}-\mathrm{k}$; sehingga nilai $\mathrm{dk}=125-5$ didapat nilai t-tabel sebesar 2,579. Hasil di atas dideskripsikan bahwa $\mathbf{H}_{0}$ ditolak dan $\mathbf{H}_{1}$ diterima, dengan demikian dapat disimpulkan bahwa jaminan memiliki pengaruh terhadap kepuasan pasien.

\section{Pengujian V : Pengaruh empati terhadap kepuasan pasien}

Hasil uji statistik pengaruh empati terhadap kepuasan pasien dengan menggunakan hipotesis :

$$
\begin{array}{lllr}
\mathrm{H}_{0}: \beta_{x 5 y}=0 & : & \begin{array}{l}
\text { Empati } \\
\text { berpengaruh terhadap }
\end{array} \\
& & \text { kepuasan pasien } \\
\mathrm{H}_{1}: \beta_{x 5 y} \neq 0 & : & \begin{array}{l}
\text { Empati berpengaruh } \\
\text { terhadap } \\
\text { pasien }
\end{array}
\end{array}
$$

Dengan kriteria uji : tolak $\mathrm{H}_{0}$ jika Sig. $<0.05$ atau $\mathrm{t}$ hitung $>\mathrm{t}$ tabel.

Tabel 9 Pengaruh Empati $\left(\mathrm{X}_{5}\right)$ terhadap kepuasan

\begin{tabular}{|c|c|c|c|c|}
\multicolumn{5}{c|}{ pasien (Y) } \\
\hline Struktural & $\begin{array}{c}\text { Koefisien } \\
\text { regresi }\end{array}$ & $\begin{array}{c}\mathbf{t} \\
\text { hitung }\end{array}$ & Sign. & Kesimpulan \\
\hline$\beta_{x 5 y}$ & 0,197 & 3,700 & 0.000 & $\begin{array}{l}\text { Ho ditolak, } \\
\text { terdapat } \\
\text { pengaruh } X_{5} \\
\text { terhadap Y }\end{array}$ \\
\hline
\end{tabular}

Sumber : data penelitian diolah, 2016

Hasil perhitungan di atas menunjukkan nilai $t$ hitung adalah 2,241 dengan tingkat signifikansi $(\alpha)=5 \%$. diperoleh nilai Sign. $=0.000$. Sesuai dengan hasil yang diperoleh yaitu Sign. ( 0.000) < 0.05 serta t-hitung $(3,700)>$ t-tabel $(1.979)$. Nilai $\mathrm{t}$-tabel didapatkan dengan rumus $\mathrm{dk}=\mathrm{n}-\mathrm{k}$; sehingga nilai $\mathrm{dk}=125-5$ didapat nilai $\mathrm{t}$-tabel sebesar 3,700. Hasil di atas dideskripsikan bahwa $\mathbf{H}_{0}$ ditolak dan $\mathbf{H}_{1}$ diterima, dengan demikian dapat disimpulkan bahwa empati memiliki pengaruh terhadap kepuasan pasien.

\section{Pengujian VI : Pengaruh bukti fisik, kehandalan, daya tanggap, jaminan dan empati terhadap kepuasan pasien.}

Hasil uji statistik pengaruh bukti fisik, kehandalan, daya tanggap, jaminan dan empati terhadap kepuasan pasien secara simultan dengan menggunakan hipotesis :

$\mathrm{H}_{0}: \beta_{\mathrm{x} 1 \mathrm{y} ;} \beta_{\mathrm{x} 2 \mathrm{y}}$, bukti fisik, kehandalan, $\beta_{\mathrm{x} 3 y} ; \beta_{\mathrm{x} 4 \mathrm{y} ;} \quad$ daya tanggap, jaminan dan $\beta_{\mathrm{x} 5 \mathrm{y}}=0 \quad$ empati tidak berpengaruh terhadap kepuasan pasien

$\mathrm{H}_{1}: \rho \beta_{\mathrm{x} 1 \mathrm{y} ;} \beta_{\mathrm{x} 2 \mathrm{y} ;}$ bukti fisik, kehandalan, $\beta_{\mathrm{x} 3 \mathrm{y} ;} ; \beta_{\mathrm{x} 4 \mathrm{y} ;}$ daya tanggap, jaminan dan $\beta_{\mathrm{x} 5 \mathrm{y}} \neq 0 \quad$ empati berpengaruh terhadap kepuasan pasien

Dengan kriteria uji : tolak $\mathrm{H}_{0}$ jika Sig. $<0.05$ atau $\mathrm{F}_{\text {hitung }}>\mathrm{F}_{\text {Tabel }}$ 
Tabel 10 Pengaruh bukti fisik $\left(\mathrm{X}_{1}\right)$, kehandalan $\left(\mathrm{X}_{2}\right)$, daya tanggap $\left(\mathrm{X}_{3}\right)$, jaminan $\left(\mathrm{X}_{4}\right)$ dan empati

$\left(\mathrm{X}_{5}\right)$ terhadap kepuasan pasien $(\mathrm{Y})$

\begin{tabular}{|c|r|r|r|l|}
\hline Struktural & $\begin{array}{c}\text { Koefisien } \\
\text { determinasi }\end{array}$ & $\begin{array}{c}\text { f } \\
\text { hitung }\end{array}$ & Sign. & Kesimpulan \\
\hline$\beta_{x 5 y}$ & 0,852 & 136,827 & 0.000 & $\begin{array}{l}\text { Ho ditolak, } \\
\text { terdapat } \\
\text { pengaruh } X_{1}, \\
X_{2}, X_{3}, X_{4} \\
\text { dan } X_{5} \\
\text { terhadap Y }\end{array}$ \\
\hline
\end{tabular}

Sumber : data penelitian diolah, 2016

Dari tabel di atas, terlihat bahwa $\mathrm{F}$ hitung adalah 136,827 dengan nilai Sign. $=0,000$, lebih kecil dari $0,05(\alpha)$, dengan demikian $\mathbf{H}_{\mathbf{0}}$ ditolak dan $\mathbf{H}_{1}$ diterima sehingga dapat disimpulkan bahwa bukti fisik $\left(\mathrm{X}_{1}\right)$, kehandalan $\left(\mathrm{X}_{2}\right)$, daya tanggap $\left(\mathrm{X}_{3}\right)$, jaminan $\left(\mathrm{X}_{4}\right)$ dan empati $\left(\mathrm{X}_{5}\right)$ berpengaruh terhadap kepuasan pasien.

\section{KESIMPULAN}

Berdasarkan uji hipotesis yang dilakuan, secara parsial baik kualitas pelayanan memiliki pengaruh positif dan signifikan terhadap kepuasan pasien di Rumah Sakit Umum Daerah Kabupaten Majalengka. Begitu juga secara simultan kedua variabel kualitas pelayanan secara bersama-sama memiliki pengaruh positif dan signifikan terhadap kepuasan pasien di Rumah Sakit Umum Daerah Kabupaten Majalengka dan dimenasi kehandalan memiliki pengaruh yang lebih dominan terhadap kepuasan pasien Rumah Sakit Umum Daerah Kabupaten Majalengka. Namun jika dilihat dari masing-masing dimensi tedapat dimensi daya tanggap tidak berpengaruh terhadap kepuasan pasien, namuan secara simultan hubungan masing-masing variabel bebas dan terkait masih dalam kategori nilai cukup meskipun bernilai positif dan signifikan.

\section{DAFTAR PUSTAKA}

Arikunto, Suharsimi. 2006. Prosedur Penelitian Suatu Pendekatan Praktik. Jakarta : Rineka Cipta.

Kotler, Philip. 2001. Manajemen Pemasaran : Analisis, Perencanaan, Implementasi, dan Kontrol. Jakarta : PT. Prehallindo.

Lupiyoadi, Rambat, 2001, Manajemen Pemasaran Jasa, Salemba Empat, Jakarta.

Tjiptono, Fandy. 2008, Strategi Bisnis Pemasaran. Andi. Yogyakarta.

Zikmund, William G, Mcleod, Raymond, Gilbert, Faye W. (2003). Customer Relationdhip Management : Integrating Marketing
Strategy and Information Technology. John Wiley and Sons.Inc, USA. 